\title{
The Impact of Service Quality, Student Satisfaction, and University Reputation on Student Loyalty: A Case Study of International Students in IIUM, Malaysia
}

\author{
${ }^{*}$ Djafri Fares ${ }^{1}$, Meguellati Achour, ${ }^{2}$ Omar Kachkar ${ }^{1}$ \\ ${ }^{1}$ International Islamic University, Kuala Lumpur, Malaysia \\ 2University of Malaya, Kuala Lumpur, Malaysia \\ *djafrifares@gmail.com
}

\begin{abstract}
The purpose of this paper is to examine the relationship between service quality, student satisfaction, university reputation, and student loyalty in the International Islamic University Malaysia (IIUM). This study aims to improve our understanding of student loyalty and to highlight the effect of student satisfaction, service quality, and brand image in building student loyalty towards IIUM. Data were randomly collected from 160 students studying in IIUM during the 2012/2013 academic session. Data analysis encompasses descriptive analysis, reliability analysis, exploratory factor analysis (EFA), correlation, and regression analysis. The data resulted in acceptably high reliability. The result indicates that all independent variables have significant impact on student loyalty. All three hypotheses were supported. This study is set to assist institutions of higher education to identify improvements in the service delivery process by identifying different aspects of service quality, brand image, and student satisfaction in IIUM.
\end{abstract}

Keywords: Student Loyalty, Student Satisfaction, Service Quality, University Reputation, Brand Image

\section{Introduction}

With the increasing significance of the service sector in the global economy beside the ever mounting competition between companies to attract new customers, educational institutions and universities are placing greater emphasis on meeting the expectation and needs of their customers "students" (Thomas, 2011). As a consequence, educational institutions are forced to commit themselves to certain quality criteria and adopt a market orientation strategy to differentiate themselves from their competitors by delivering superior quality services (Thomas, 2011). In line with this, Poole et al., (2000) noted that universities facing high competitive and commercial environment often turn to the strategy of addressing the quality of services delivered and related factors as a means of achieving a competitive advantage in this increasingly challenging environment (p.18). Student (customer) loyalty is supposed to be positively related to student (customer) satisfaction and the performance of an educational institution. Oliver (1997) mentioned that satisfaction with the entity, for example a product or a service, is based on experience. On the other hand, Ravald and Grönroos (1996) stated that customers' appreciation is not only the focal product, but is the organization supplying the product or services. Accordingly, both the satisfaction experienced and the reputation (image) of the supplier are important for customer loyalty (Zabala et al., 2005). Therefore, the purpose of this paper is to examine the relationships between service quality, student satisfaction, university reputation (image), and student loyalty in the International Islamic University Malaysia (IIUM). Accordingly, the primary objectives of this research are:

- To examine the relationship between service quality and student loyalty;

- To determine the relationship between student satisfaction and student loyalty;

- To determine the relationship between university reputation (image) and student loyalty.

\section{Literature Review}

Service quality is a critical factor for developing and sustaining relationships with customers (Park et al., 2006). Since it has significant impact on customer satisfaction and customer loyalty to service firms, this construct is a major determinant of firm success or failure in a competitive environment (Lin et al., 2009). Service quality is the discrepancy between consumers' perceptions of services offered by a particular firm and their expectations about the firms offering such services (Chou et al., 2011). Hernon and Nitecki (2001) 
noted that definitions of service quality are based on four main perspectives. The first perspective is 'excellence', which is often externally defined. Second view is 'value', which incorporates multiple attributes and is focused on benefit to the recipient. The third perspective is conformance to specifications', which enables precise measurement, but customers may not know or care about internal specifications. Finally, meeting and/or exceeding expectations', which is all-encompassing and applies to all service industries? Ramaiyah et al. (2007) classified service quality into four underlying classifications, namely expected service, which refers to the services that the customer expects from the service provider; desired service, which refers to the level of service that the customer wishes to obtain; adequate service, which refers to the minimum level of services that the customer expects from the service provider, and finally, predicted service, which is what the customer thinks the company will perform. Among the earliest to speak about service quality is Parasuraman et al. (1985).In his paper "A Conceptual Model of Service Quality and its Implications on future Research"; he identifies 10 determinants of service quality: Access, Communication, Competence, Courtesy, Credibility, Reliability, Responsiveness, Security, Tangibles, and Customer Knowledge. However, in a later paper he reduced the 10 determinants into 5 dimensions using factor analysis. These dimensions are Tangibles, Reliability, Responsiveness, Assurance, and Empathy.

Interestingly, many studies have emphasized on the importance of service quality in educational institutions (Airey \& Bennett, 2007; Shekarchizadeh et al., 2011; Annamdevula \& Bellamkonda, 2012). Shekarchizadeh et al. (2011) analyses the educational service quality of selected Malaysian universities based on the modified service quality (SERVQUAL) instrument developed for international post-graduate students. More specifically, the objective of their research was to measure the service quality perceptions and expectations of international post-graduate students in selected Malaysian universities. The authors found that the modified SERVQUAL scale developed to measure postgraduate students' perceptions of education service quality is statistically reliable. Moreover, this study found that international postgraduate students have negative perception of education service quality in the five selected universities. Besides that, students were dissatisfied with the service quality of education on all the five dimension quality factor. Annamdevula and Bellamkonda (2012) developed a measuring instrument of service quality called HiEdQUAL. This new measuring instrument consists of 27 items divided into five dimensions, which they found to have significant positive influence on overall students' perceived service quality. The five factors are: teaching and course content, administrative services, academic facilities, campus infrastructure, and support services of service quality within the higher education sector.

Besides that, satisfying customers is an important element in marketing theory as customer satisfaction affects future consumer purchase behaviour (Yoo \& Park, 2007). According to Tse and Wilton (1988) customer satisfaction is the consumers' response to evaluation of the perceived discrepancy between prior expectation and actual performance of the product as perceived after its consumption. The concept of students' satisfaction has been defined by several researchers as "a short-term attitude resulting from an evaluation of student's educational experience" (Elliott \& Healy, 2001, p. 2), or as "a comparison between the experience obtained in the university and expectation to that experience" (Alves \& Raposo, 2007). Brand image (reputation) has been recognized as one of the central tenets of marketing research, not only because of its role as a foundation for tactical marketing but also for its role in building long-term brand equity (Keller, 1993). Dick and Basu (1994) mentioned that image and reputation are important elements to develop and maintain a loyalty relationship with customers. According to Airey and Bennett (2007) one of the main factors for international students when searching for the right institution to pursue their studies is the reputation (image) of the institution or the organization. Helgesen and Nesset (2007) noted that both the image of a university and the image of a study program of a university are assumed to have positive effects on student loyalty.

To sum up, the following hypotheses are proposed for this study:

H1 Service Quality (SQ) has a significant direct impact on Student Loyalty (SL)

H2 Students satisfaction has a significant direct impact on Student Loyalty (SL)

H3 University Reputation (UR) has a significant direct impact on Student Loyalty (SL) 


\section{Methodology}

Participants and Procedure: Data were randomly collected from 160 international students studying at the International Islamic University Malaysia during the 2012/2013 academic session. A total of 148 questionnaires were returned with a response rate of approximately 92 percent. The ages of respondents ranged from 18 to 45 years of age. Rapport was established by explaining the importance and the relevance of the study. Participants were assured that their responses would be kept confidential and utilized only for the research purpose. They were asked to complete the questionnaires by following the instructions written at the top of the questionnaire. The questionnaires were distributed at the International Islamic University where students would gather in the campus from various countries.

Measures: Measures for independent and dependent variables used a seven-point Likert type response format, with "strongly disagree" and "strongly agree". The respondents recorded their assessment of the items on seven-point Liker type scales ( $1=$ strongly disagree, $2=$ disagree, $3=$ somewhat disagree, $4=$ neither agree nor disagree, $5=$ somewhat agree, $6=$ agree, $7=$ strongly agree). A self-administrated questionnaire was pretested with 20 international students studying in IIUM. The purpose of the research was explained to the students in an effort to facilitate the respondents' feedback, suggestions, and answering of the questions (Achour et al., 2011). The respondents suggested that some words in the questions were not clear or straightforward. Except for these comments, the results of the pre-test indicated that, on an overall level, the questions were realistic, clear, and easy to follow. Following the pre-test, the unclear words and sentences were revised (Achour et al., 2011).

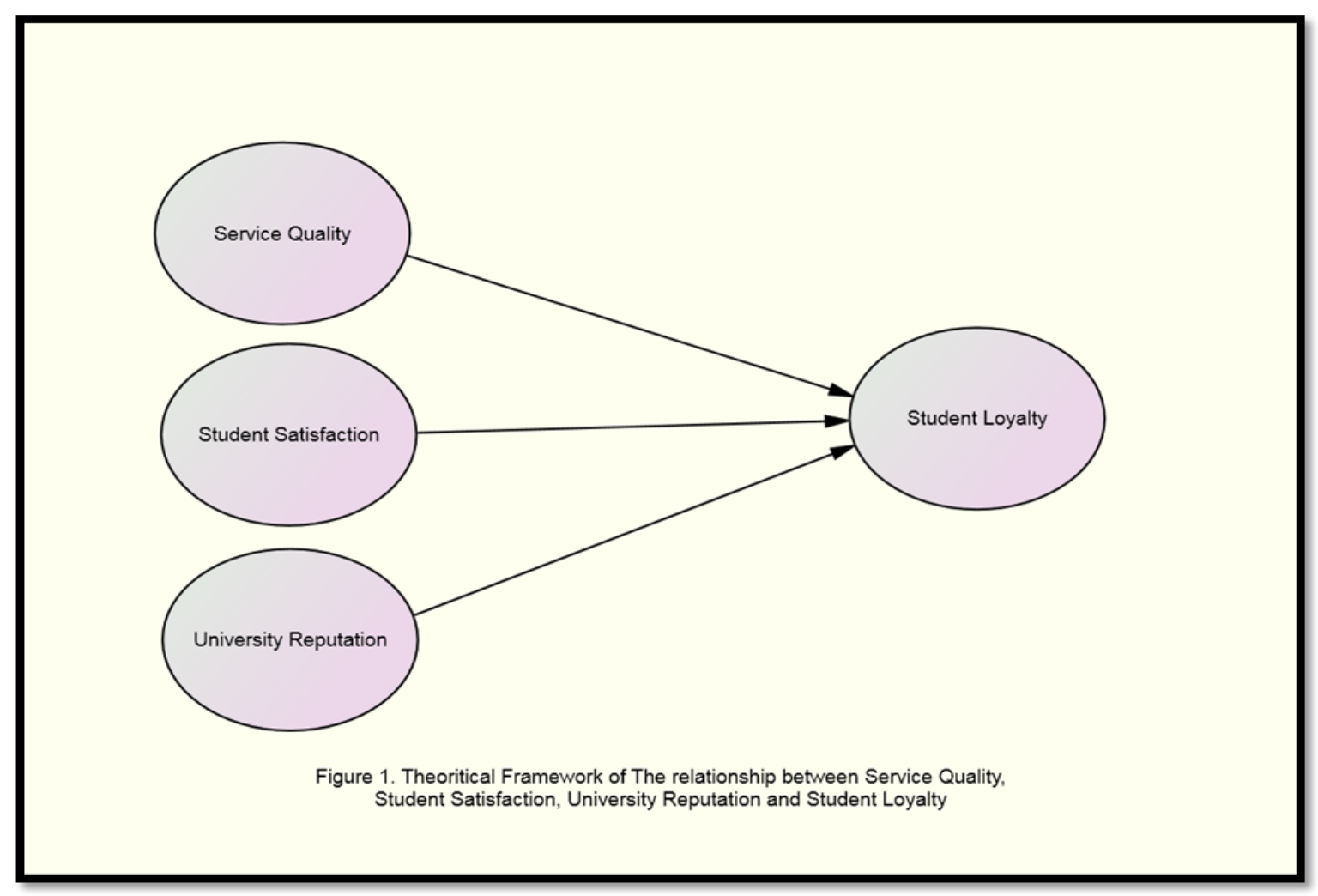

\section{Results}

Factor Analysis: The data is analysed using exploratory factor analysis (EFA), through principal components analysis (PCA) with the varimax rotation method. According to Costello and Osborne (2007), PCA is a data reduction method used to reduce the number of items in a survey questionnaire. To assess the reliability of the scale, Cronbach's alpha coefficient was calculated for each variable and within each factor solution. All factors had coefficients greater than 0.70, indicating evidence of reliability. Hair et al. (2010) noted that one of the common measures for coefficient reliability is Cronbach's alpha, which assesses the consistency of the 
entire scale (p.125). The minimum acceptable level is 0.70. However, Hair et al. (2010) admitted that in exploratory research 0.6 is acceptable.

Table 1: Varimax-rotated factor loadings

\begin{tabular}{|c|c|c|c|c|c|}
\hline No & Items & Factor: & & & \\
\hline & & F1 & F2 & F3 & F4 \\
\hline 12 & The employees of IIUM are courteous. & .510 & & & \\
\hline 13 & The employees of IIUM are willing to help students & .725 & & & \\
\hline 14 & $\begin{array}{l}\text { The employees of IIUM give international students personal } \\
\text { attention. }\end{array}$ & .794 & & & \\
\hline 15 & $\begin{array}{l}\text { The employees of IIUM are able to answer students' } \\
\text { questions in a satisfactory way }\end{array}$ & .762 & & & \\
\hline 16 & The employees of IIUM provide services promptly and timely & .775 & & & \\
\hline 17 & The employees of IIUM gave you individual attention. & .728 & & & \\
\hline 19 & $\begin{array}{l}\text { The employees of IIUM had knowledge to answer your } \\
\text { questions. }\end{array}$ & .617 & & & \\
\hline 21 & IIUM understood your specific needs. & .655 & & & \\
\hline 22 & IIUM showed honest interest solving your problem. & .608 & & & \\
\hline 1 & Overall, I am satisfied with the university. & & 663 & & \\
\hline 2 & I have always had a good impression of IIUM & & 632 & & \\
\hline 5 & $\begin{array}{l}\text { Lecturers and students communicating with each other } \\
\text { smoothly in teaching class. }\end{array}$ & & .722 & & \\
\hline 6 & $\begin{array}{l}\text { I am satisfied with the quality of teaching service that } \\
\text { lecturers providing for students. }\end{array}$ & & .705 & & \\
\hline 7 & The teaching services provided by lecturers are convenient. & & .724 & & \\
\hline 4 & My experiences with IIUM exceed my expectations. & & & .468 & \\
\hline 24 & I believe that IIUM has a better image than other universities. & & & 618 & \\
\hline 27 & $\begin{array}{l}\text { I believe that IIUM provides more benefits than other } \\
\text { universities. }\end{array}$ & & & .708 & \\
\hline 28 & $\begin{array}{l}\text { No other university in Malaysia performs services better than } \\
\text { IIUM. }\end{array}$ & & & .708 & \\
\hline 29 & $\begin{array}{l}\text { I am willing to pay more to study in IIUM than in other } \\
\text { universities. }\end{array}$ & & & 697 & \\
\hline 18 & I like studying in IIUM. & & & 602 & \\
\hline 9 & I believe it is a good university. & & & .545 & \\
\hline 10 & I will continue to recommend this university to others. & & & 642 & \\
\hline 11 & I consider IIUM my first choice. & & & .537 & \\
\hline 3 & $\begin{array}{l}\text { I think that I did the right thing when I decided to study in } \\
\text { IIUM. }\end{array}$ & & & & .568 \\
\hline 8 & $\begin{array}{l}\text { Considering the services that IIUM offers, they are worth } \\
\text { what I pay for them. }\end{array}$ & & & & .557 \\
\hline 20 & $\begin{array}{l}\text { IIUM has modern equipment' and physical facilities that } \\
\text { conform to services provided. }\end{array}$ & & & & .565 \\
\hline 23 & $\begin{array}{l}\text { In my opinion, IIUM has a good image in the minds of } \\
\text { international students. }\end{array}$ & & & & .681 \\
\hline 25 & My choice to study at IIUM was a wise one. & & & & .642 \\
\hline \multirow[t]{3}{*}{26} & IIUM has a good reputation. & & & & .569 \\
\hline & Coefficient Alpha $(\alpha)$ & .936 & .864 & .931 & .889 \\
\hline & Eigen values & 16.07 & 2.51 & 1.91 & 1.55 \\
\hline
\end{tabular}


Table 1 gives the details of the factor analysis. There have been many studies in which it has been found that extracting factors on the basis of the Eigen values greater than 1 can lead to an over estimation of the number of retained factors (Henson \& Roberts, 2006). Therefore, based on this, the Eigen values of the factors retained in this study were taken as being greater than 1 . This also reduces the risk of over-factoring, which implies that retaining factors that have little theoretical basis can lead to misinterpretation and they may not lead to replicability of results (Gorsuch, 1983; Fabrigar et al., 1999; Henson \& Roberts, 2006). Besides, the analysis made use of the varimax factor rotation procedure. Hair et al. (2010) stated that varimax rotation seeks loadings that maximize the variance of the squared loadings for each factor; the goal is to make some of these loadings as large as possible, and the rest as small as possible in absolute value. The result of the factor analysis in terms of factor name, rotated factor loading matrices, the variance explained by each factor, and the result of reliability test coefficient alphas can be seen in (Table 1). The Kaiser-Meyer-Olkin (KMO) measure of sampling adequacy was computed to quantify the degree of inter-correlations among the variables, and the result indicates an index of 0.926. Since a high-KMO is achieved, the dataset is appropriate for factor analysis (Hair et al., 2010). After the purification procedure, the four factors are defined as service quality, student's satisfaction, university reputation, and loyalty of students. When added together, the four factors account for 70.445 per cent of the sum of all observed variances. In other words, 70.445 per cent of the variation in the data generated.

Internal Consistency: The Cronbach's alpha correlation coefficient for service quality was .936, Cronbach's alpha correlation coefficient for student's satisfaction was .864, the coefficients for customer loyaltywas.931, and Cronbach's alpha correlation coefficient for reputation and image was .889. This result implies high internal consistency reliability (Cronbach \& Shavelson, 2004).

\section{Correlation Matrix}

Table 2: Means, Standard Deviations, and Correlations of the variables

\begin{tabular}{lllllll}
\hline Variable & $\mathbf{M}$ & S.D & $\mathbf{1}$ & $\mathbf{2}$ & $\mathbf{3}$ & $\mathbf{4}$ \\
\hline 1. Customer Loyalty & 40.43 & 12.19 & 1 & & & \\
2. Students Satisfaction & 23.66 & 5.69 & $.705^{* *}$ & 1 & & \\
3. Service Quality & 35.61 & 11.46 & $.691^{* *}$ & $.618^{* *}$ & 1 & \\
4. Reputation and Image & 28.85 & 7.36 & $.787^{* *}$ & $.666^{* *}$ & $.693^{* *}$ & 1 \\
\hline
\end{tabular}

${ }^{*} P<.05 .{ }^{* *} P<.01$.

Table 2 shows that there exists a positive and significant correlation of customer loyalty with students satisfaction $(\mathrm{r}=.705, \mathrm{p}<.01)$, service quality $(\mathrm{r}=.691, \mathrm{p}<.01)$, and reputation and image $(\mathrm{r}=.787, \mathrm{p}<.01)$. Students satisfaction shows a significant and positive correlation with service quality $(\mathrm{r}=.618, \mathrm{p}<.01)$ and reputation and image $(\mathrm{r}=.666, \mathrm{p}<.01)$. In addition, Table 2 shows service quality has a positive and significant correlation with reputation and image $(r=.693, \mathrm{p}<.01)$.

Regression Analysis: Table 3 shows that the results of all the independent variables are positively correlated with student loyalty. The correlations among all variables are statistically significant. This means that student satisfaction, service quality, student (customer) loyalty, and university reputation are related. This study examined the effect of student satisfaction, service quality, and university reputation on customer loyalty. The results of this study revealed that service quality $(\beta=.211$, $\mathrm{t}$-value $=2.991, \mathrm{p}<.01)$, student's satisfaction $(\beta=$ $.577, \mathrm{t}$-value $=4.192, \mathrm{p}<.01)$, and reputation and image $(\beta=.779, \mathrm{t}$-value $=6.706, \mathrm{p}<.01)$ had a significant and strong positive influence on customer (student) loyalty. Meaning that whenever there is 1 point increase in service quality, student satisfaction, and university reputation will influence student loyalty to increase by 2.991, 4.192, and 6.706 points respectively. In other words, the higher the service quality, student satisfaction, and university reputation provided by IIUM, the stringer the loyalty of students towards IIUM. All the hypotheses H1, H2, and H3 were supported. Moreover, the multicollinearity problem does not exist among all independent variables because the tolerance values are more than .10 and VIF values are less than 10. Thus, the result suggests that the current study does not have any problem with multicollinearity. 
Table 3: Regression analysis

\begin{tabular}{|c|c|c|c|c|}
\hline \multirow[b]{2}{*}{ Variables } & \multirow[b]{2}{*}{ B (t-value) } & \multirow[b]{2}{*}{ Sig } & \multicolumn{2}{|c|}{ Collinearity Statistics } \\
\hline & & & Tolerance & (VIF) \\
\hline Service Quality & $\begin{array}{l}.211 \\
(2.991)\end{array}$ & .003 & 0.476 & 2.103 \\
\hline Students Satisfaction & $\begin{array}{l}.577 \\
(4.192)\end{array}$ & .000 & 0.509 & 1.963 \\
\hline Reputation and Image & $\begin{array}{l}.779 \\
(6.706)\end{array}$ & .000 & 0.428 & 2.337 \\
\hline R Square & .697 & & & \\
\hline $\begin{array}{l}\text { Adjusted R Square } \\
\text { Sig. F Change }\end{array}$ & $\begin{array}{l}.691 \\
.000\end{array}$ & & & \\
\hline
\end{tabular}

\section{Conclusion}

This study sought to examine the impact of service quality, students' satisfaction, and university reputation on student loyalty IIUM. For this purpose, we used EFA and multiple linear regression analysis. The findings of this study show that the regression model significantly explains the dependent variable as $\mathrm{R}^{2}$ is 0.69 showing that the model is strong enough to explain the variability of student loyalty in IIUM. The results of this study also revealed that service quality, student satisfaction, and university reputation have positive effects on student loyalty. For the implications, the higher the service quality, student satisfaction, and image provided by IIUM, the higher the loyalty of students toward it. The study has limitations with respect to sampling and hence the findings of this study should be applied in the light of the fact that the study is conducted over a small sample size, which may limit the generalizability of the results and representativeness of the population area. Nevertheless, the findings from the study have great value for academic institutions elsewhere.

\section{References}

Achour, M., Md Said, N. P. \& Boerhannoeddin, A. (2011). Customer loyalty: The case of mobile phone users in Universiti Utara Malaysia. International Journal of Management Studies (IJMS), 18(2), 43-66.

Airey, D. \& Bennett, M. (2007). Service Quality in Higher Education: The Experience of Overseas Students. Journal of Hospitality, Leisure, Sport \& Tourism Education, 6(2), 1473-8376.

Alves, H. \& Raposo, M. (2007). Conceptual model of student satisfaction in higher education. Total Quality Management, 18(5), 571-588.

Annamdevula, S. \& Bellamkonda, R. S. (2012). Development of HiEdQUAL for Measuring Service Quality in Indian Higher Education Sector. International Journal of Innovation, Management and Technology, 3(4), 2012.

Chou, C. C., Liu, L. J., Huang, S. F., Yih, J. M. \& Han, T. C. (2011). An evaluation of airline service quality using the fuzzy weighted SERVQUAL method. Applied Soft Computing, 11(2), 2117-2128. Doi: 10.1016/j.asoc.2010.07.010

Costello, A. B. \& Osborne, J. W. (2007). Practical Assessment, Research \& Evaluation. A peer-reviewed electronic journal, 10(7), 1531-7714.

Cronbach, L. J. \& Shavelson, R. J. (2004). My current thoughts on coefficient alpha and successor procedure. Educational and Psychological Measurement, 64(3), 391- 418.

Dick, A. S. \& Basu, K. (1994). Customer loyalty: toward an integrated conceptual framework. Journal of the academy of marketing science, 22(2), 99-113.

Elliott, K. M. \& Healy, M. A. (2001). Key factors influencing student satisfaction related to recruitment and retention. Journal of Marketing for Higher Education, 10(4), 1-11.

Fabrigar, L. R., Wegener, D. T., MacCallum, R. C. \& Strahan, E. J. (1999). Evaluating the use of exploratory factor analysis in psychological research. Psychological Methods, 4, 272-299.

Gorsuch, R. L. (1983). Factor analysis (2nd Ed.). Hillsdale, NJ: Lawrence Erlbaum. 
Hair, J. F., Black, W. C., Babin, B. J. \& Anderson, R. E. (2010). Multivariate Data Analysis, $7^{\text {th }}$ edn. Prentice Hall, Upper Saddle River, $N J, 07458$

Helgesen, Ø. \& Nesset, E. (2007). Images, satisfaction and antecedents: Drivers of student loyalty? A case study of a Norwegian university college. Corporate Reputation Review, 10(1), 38-59.

Henson, R. K. \& Roberts, J. K. (2006). Use of exploratory factor analysis in published research. Educational and Psychological Measurement, 66(3), 393-416.

Hernon, P. \& Nitecki, D. (2001). Service Quality: A Concept not fully explored. Library Trends, 49, 687-708.

Keller, K. (1993). Conceptualizing, measuring, and managing customer-based brand equity. Journal of Marketing, 57(1), 1-22.

Lin, S. P., Chan, Y. H. \& Tsai, M. C. (2009). A transformation function corresponding to IPA and gap analysis. Total Quality Management \& Business Excellence, 20(8), 829-846.

Oliver, R. L. (1997). Satisfaction: A Behavioral Perspective on the Consumer, McGraw-Hill, New York, NY.

Parasuraman, A., Zeithaml, V. A. \& Berry, L. L. (1985). A Conceptual Model of Service Quality and its Implications for Future Research. Journal of Marketing, 49, 41-50.

Park, J. W., Robertson, R. \& Wu, C. L. (2006). Modelling the Impact of Airline Service Quality and Marketing Variables on Passengers' Future Behavioural Intentions. Transportation Planning and Technology, 29(5), 359-381. doi: 10.1080/03081060600917686 pp. 391-418.

Poole, M., Harman, E., Snell, W., Deden, A. \& Murray, S. (2000). ECU Service 2000: A client-centred transformation of corporate services, 00/16. Canberra: Evaluations and Investigations Programme. Higher Education Division, Department of Education, Training and Youth Affairs.

Ramaiyah, A., Zain, M., Nurulazam, A. \& Ahmad, H. (2007). Exploring the dimensions of service quality in higher education research. Retrieved from http://eprints.um.edu.my/16/1/arivalan.pdf 8 Nov 2013.

Ravald, A., \& Grönroos, C. (1996). The value concept and relationship marketing. European journal of marketing, 30(2), 19-30.

Shekarchizadeh, A., Rasli, A. \& Hon-Tat, H. (2011). SERVQUAL in Malaysia Universities: perspectives of international students. Business Process Management Journal, 17(1), 67-81.

Thomas, S. (2011). What Drives Student Loyalty in Universities: An Empirical Model from India. International Business Research, 4(2), 183-192.

Tse, D. K. \& Wilton, P. C. (1988). Models of consumer satisfaction formation: An extension. Journal of Marketing Research, 25(2), 204-212.

Yoo, D. K. \& Park, J. A. (2007). Perceived service quality - analyzing relationships among employees' customers, and financial performance. International Journal of Quality \& Reliability Management, 24(9), 908-926.

Zabala, I., Panadero, G., Gallardo, L. M., Amate, C. M., SA 'nchez-Galindo, M., Tena, I. \& Villalba, I. (2005). Corporate reputation in professional services firms: reputation management based on intellectual capital management. Corporate Reputation Review, 8 (1), 59-71. 